\title{
LEPIDOPHLOIOS ACEROSUS LINDLEY AND HUTTON 1831 IN THE CARBONIFEROUS CUCUIOVA FORMATION, “IRON GATES” NATURAL PARK (BANAT, ROMANIA)
}

Mihai Emilian POPA *

* University of Bucharest, Faculty of Geology and Geophysics, Laboratory of Paleontology, Mihail Kogălniceanu Street 36-46, Bucharest, Romania, RO-010041, mihai@mepopa.com

DOI: 10.1515/trser-2015-0029

KEYWORDS: Cucuiova Formation, Carboniferous, fossil plants, Sirinia Basin, Almăj Mountains, "Iron Gates” Natural Park.

\section{ABSTRACT}

The Carboniferous Cucuiova Formation of the Sirinia Basin, Danubian Units, in Almăj Mountains, South Carpathians, yields a highly diverse yet rare compressive flora representing significant heritage values of the "Iron Gates" Natural Park. This flora includes pteridophytes (lycopsids, sphenopsids, filicopsids) and gymnosperms (pteridosperms and conifers), some of these representatives being important coal generators during the Late Carboniferous times. The facies features, distribution and paleofloral features of the Cucuiova Formation are discussed in the framework of the Sirinia Basin. The lycopsid Lepidophloios acerosus Lindley and Hutton 1831 is reported for the first time in Romania from the Cucuiova Formation in Dragosela Valley, in the central part of the "Iron Gates" Natural Park.

RÉSUMÉ: Lepidophloios acerosus Lindley et Hutton 1831 dans la Formation Carbonifère de Cucuiova, Parc Naturel des "Portes de Fer".

La Formation Carbonifère de Cucuiova, bassin de Sirinia, Unités Danubiennes, Monts des Almăj, dans les Carpathes de Sud, inclue une flore compressive rare et diverse à forte valeur patrimoniale pour le Parc Naturel des Portes de Fer. Cette flore inclue des ptéridophytes (lycopsides, sphénopsides, filicopsides) et des gymnospermes (ptéridospermes et conifères), quelques unes d'entre elles ont été des carbogénératrices importantes durant le Carbonifère tardif. Les caracteristiques de facies, la distribution et les caracteristiques paléofloristiques de la Formation de Cucuiova sont discutées dans le cadre du bassin de Sirinia. Le lycopside Lepidophloios acerosus Lindley et Hutton 1831 est rapporté pour la première fois en Roumanie, dans la Formation de Cucuiova, Valle de Dragosela, dans la partie moyenne du Parc Naturel des Portes de Fer.

REZUMAT: Lepidophloios acerosus Lindley și Hutton 1831 în Formațiunea carboniferă de Cucuiova, Parcul Natural „Porțile de Fier”.

Formaţiunea de Cucuiova, de vârstă carboniferă, din cadrul Bazinului Sirinia, Unitățile Danubiene, Munții Almăj, Carpații de Sud, cuprinde o floră compresivă diversă și rară, reprezentând valori patrimoniale semnificative ale Parcului Natural „Poțile de Fier”. Această floră include pteridofite (lycopside, sfenopside, filicopside) și gimnosperme (pteridosperme și conifere), unele dintre acestea fiind carbogeneratori importanți în timpul Carboniferului târziu. Caracteristicile faciale, distribuția și caracteristicile paleofloristice ale Formațiunii de Cucuiova sunt discutate în cadrul Bazinului Sirinia. Lycopsidul Lepidophloios acerosus Lindley şi Hutton 1831 este raportat pentru prima dată în România, din cadrul Formațiunii de Cucuiova, pe Valea Dragosela, în partea centrală a Parcului Natural „Poțile de Fier”. 


\section{INTRODUCTION}

The Sirinia Basin, also known as the Sviniţa-Svinecea Mare sedimentary zone, represents a part of the sedimentary cover of the Upper (Internal) Danubian Units, developed mainly within the structures of the Almăj Mountains, South Carpathians, in Romania. This basin includes Palaeozoic and Mesozoic sedimentary cycles, the Palaeozoic cycle yielding Carboniferous and Permian Formations. The central and southern parts of the Almăj Mountains, where Carboniferous deposits mainly outcrop, occur in the middle area of the "Iron Gates” Natural Park, the second largest natural park in Romania. These deposits yield rare yet diversified plant fossils, their rarity being related to the scarcity of Carboniferous outcrops in the area, as well as to the low potential of fossilisation in the area.

The Carboniferous deposits of the Sirinia Basin (Sviniţa-Svinecea Mare sedimentary zone) were known since the XIXth Century, when the first studies were published by Hauer (1870), Schafarzik (1894, 1912), Stur (1870) and Tietze (1872); while a contribution dealing with these deposits in a wider geological synthesis was provided by Codarcea (1940). Detailed research was later published by Răileanu (1953), including an inventory of Carboniferous outcropping areas in the Sirinia Basin, and a detailed geological map (Răileanu et al., 1963). Năstăseanu et al. (1973) attempted a general correlation of Carboniferous and Permian deposits, followed by the work of Stănoiu and Stan (1986) dealing with the formal definition of the Cucuiova Formation. The subject was detailed also in various textbooks, such as in Petrescu et al. (1987), Preda et al. (1994) and Răileanu et al. (1963).

Later paleobotany works dealing with the Carboniferous coal flora of the Sirinia Basin were published by Biţoianu (1972a, b, 1973, 1974, 1987), Dragastan et al. (1997), Maxim (1967, 1969), Popa and Cleal (2012), and Semaka (1962, 1970). Biţoianu (1966), Ilie and Biţoianu (1967), and Biţoianu and Ilie (1968) described fungal remains in coal petrography studies. A general revision of this flora, based on previous works and also of the early paleobotanical contributions of Hantken (1878) and Schafarzik (1894), was published by Popa (2005), who also stressed the main difficulties when undertaking paleobotanical studies in the area: the disappearance of the previous paleobotany type collections, the low quality of outcrops, and the scarcity of illustrated or described taxa in previous papers. The type collections are missing almost entirely, excepting several hand specimens partly figured in Maxim (1969), curated at the "Babeş-Bolyai" University, and an unpublished hand specimen from Cucuiova found in the Silvia Cotuţiu collection, curated at the Bucharest Geological Museum. Another difficulty is the unclear recorded geographical, local names in the region, where valleys and hills were not formally recorded, and they differ from author to author. Popa (2005) detailed the systematic lists of the Cucuiova Formation, together with updates on the lithological logs of the same formation; therefore this type of information will not be reiterated.

\section{The Cucuiova Formation}

Recent fieldwork undertaken by the author and his collaborators using GPS gear and GIS methods in the Sirinia Basin showed again the evidence of covered outcrops, as well as the emergence of new, although smaller outcrops, such as those along the Dragosela Valley.

The Carboniferous System in the Sirinia Basin is represented by the Cucuiova Formation (Stănoiu and Stan, 1986). Its stratotype was defined by Stănoiu and Stan (1986) in the Cucuiova Hill - Povalina Valley with its tributaries Coşarnița, Zelenii (Ielenii), Zlana, Pepelaria and Drena creeks, where the sequence was considered Westphalian - Stephanian in age, based on previous paleobotanical information (Fig. 1). The local structure is represented 
by the Cucuiova syncline, where the Carboniferous deposits reach about $300 \mathrm{~m}$ in thickness, including conglomerates, sandstones, mudstones and thin coal seams. The syncline includes also the Permian terrigenous and volcanoclastic sequences, formerly defined by Stănoiu and Stan (1986) as the Povalina (terrigenous) and Trescovăţ (volcanoclastic) formations. The outcrops are scarce, as the Cucuiova Formation was recorded mainly to the east and north-east of the Cucuiova Hill. Fossil material was recently collected by the author's team in 2012-2014 through digging along the Drena Creek slopes, in an attempt to rediscover Maxim's outcrops.

The Dragosela Valley is another significant area in the Sirinia Basin, where the Cucuiova Formation outcrops (Răileanu, 1953; Biţoianu, 1972b), between the confluence of Dragosela and Tulinecea and Berzasca (Valea Mare) rivers, in the Debelilug area to the west, and towards the confluence of the Dragosela and Dragosela Mică rivers, to the east, north of the Tulinibreg Hill (Fig. 1). Here, the Cucuiova Formation has a syncline structure, as a part of the larger Sirinia Syncline, outcropping along the valley in 14 outcrops of various sizes. A former exploration gallery was found, probably the former G3 gallery of Biţoianu (1972b), as well as one supplementary sterile dump. The newly collected flora is badly preserved, including a Lepidophloios acerosus Lindley and Hutton 1831 fragment curated in the University of Bucharest, described here. Here, quartzite conglomerates, quartzite, micaceous, coarse grained sandstones were found overlaying the Ielova metamorphic series, together with finer sediments such as mudstones and fine, black or brownish sandstones and centimetric coals. Biţoianu (1972b) cited a floral assemblage marking the Westphalian D - lower Cantabrian interval, but the illustrations are difficult to interpret, as well as the taxonomic composition. Popa (2005) reinterpreted the age of the Cucuiova Formation in Dragosela as Bolsovian - Westphalian D - Cantabrian (Westphalian C - Stephanian).

Baia Nouă is another important area where the Cucuiova Formation was intensively mined (Fig. 1). The local structure is represented by a funnel shaped syncline, the former mine having two main horizons for the extraction of a high quality bituminous coal seam. The age of the Cucuiova Formation in Baia Nouă, based on the fossil flora, was considered by Biţoianu (1972a, 1974) as Bolsovian (Westphalian C) - lower Westphalian D. Here, the outcrops were cited by Răileanu (1953) along the Tişoviţa Valley, and by Biţoianu $(1973,1974)$ along the Tişoviţa Valley, Popesc Creek and the Cărbunari Creek, but today these outcrops are missing. The sterile dump permitted collecting fresh material including Neuralethopteris rectinervis (Kidston) Laveine 1967 and Neuralethopteris schlehanii (Stur) Cremer 1893, described and illustrated by Popa and Cleal (2012). This assemblage indicates the basal sequences of the Cucuiova Formation in Baia Nouă as Langsettian (Westphalian A) in age, the oldest Pennsylvanian age in the Sirinia Basin and in the South Carpathians.

According to Răileanu (1953), the Cozile Valley records the flank of the reversed Sirinia Syncline with Carboniferous and Permian sediments, caught under basement rocks (Fig. 1). Recent field work showed the occurrence of small Permian outcrops represented by red beds and lacustrine limestone lenses, but no outcrops yielding Carboniferous sediments. A former exploration gallery was found in Cozilele Valley, where under red beds sequences occur black, coaly clays which may indicate the Carboniferous age.

The Cucuiova Formation was recorded also in the eastern part of the Sirinia Basin, upstream of the Mraconia River, where the Carboniferous sediments outcrop along a northsouth oriented stripe, unconformably overlying the basement (Fig. 1). Also, an outcrop with possible Carboniferous conglomerates was recorded by Răileanu (1953) upstream of the Stariştea (Staricica) Valley. 


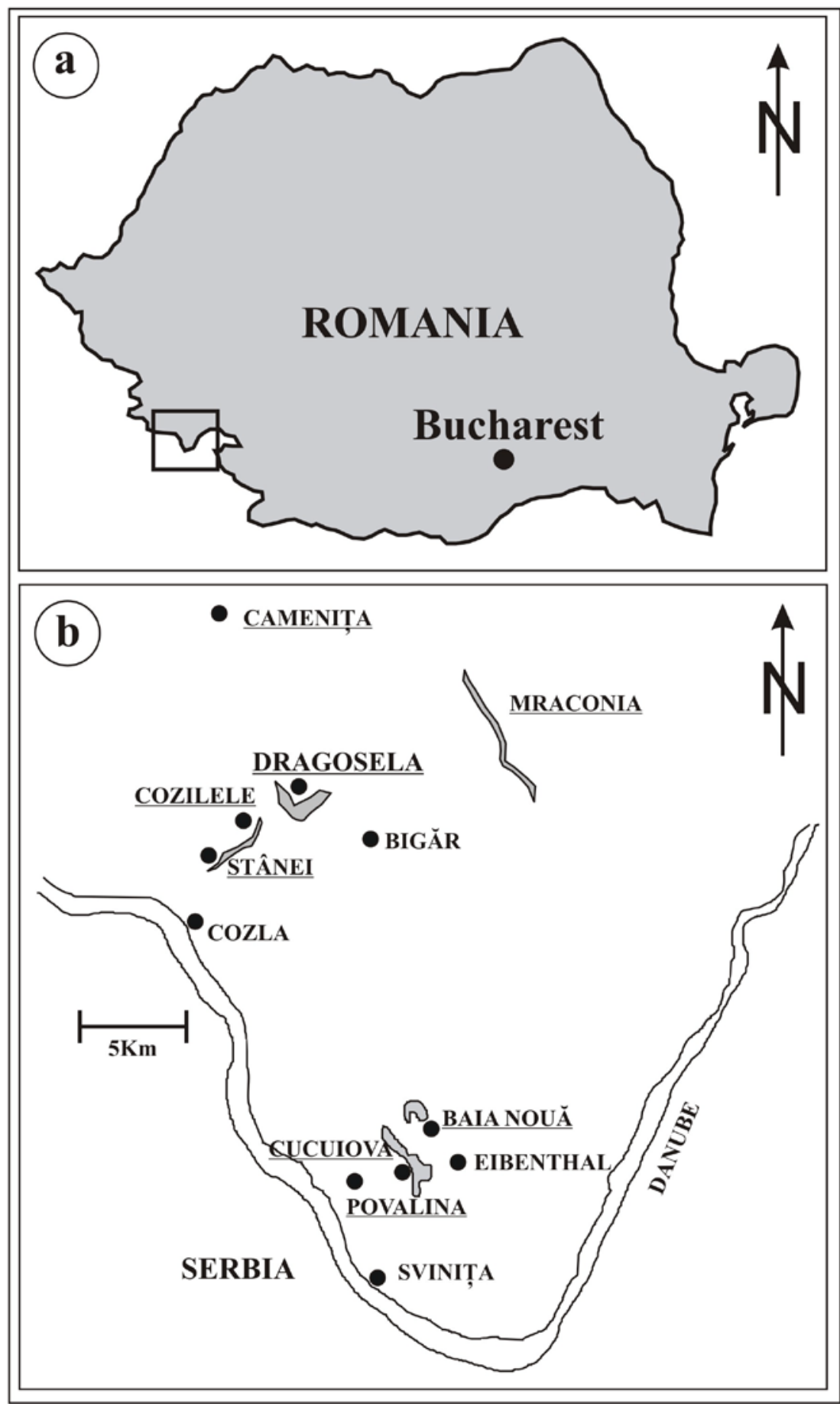

Figure 1 a: Occurrence of the studied area in the South Carpathians, Romania; b: Outcrops of the Carboniferous Cucuiova Formation, in grey, with fossil plant occurrences (underlined); modified from Popa (2005), and Popa and Cleal (2012). 


\section{MATERIAL AND METHODS}

The studied material consists of rather poorly preserved compressions, stored within the collections of the Laboratory of Palaeontology, Faculty of Geology and Geophysics, University of Bucharest. In the field, paleobotanical material was collected from small sized outcrops or from sterile dumps of the former coal mines (Popa, 2011). A Garmin GPSmap 62s unit was used in order to record accurately the occurrences. In the laboratory, the material was studied using a Carl Zeiss Stemi 2000-C dissecting microscope with a Canon Powershot A640 digital camera attached. Close-up images were taken using a Panasonic DMC-L10 digital camera with an Olympus Zuiko $35 \mathrm{~mm}$ macro lens and a Kaiser copy-stand with two Ikea lateral lights (Popa, 2011). Garmin Basecamp software was used for interpretation of geographical data and Corel Draw was used to prepare illustrations.

\section{Systematics}

The Carboniferous flora of the Cucuiova Formation is represented by pteridophytes and gymnosperms. This paleoflora is compressive and coal generating, as it generated the bituminous coals extracted from Baia Nouă and explored from Dragosela, Cozilele, Stânei, Cucuiova and Povalina valleys. Popa (2005) and Popa and Cleal (2012) updated the general list of taxa and described the paleoflora of the Baia Nouă mine. Regarding the Carboniferous paleobotanical heritage of the Sirinia Basin, Popa (2003) advanced the idea that the sterile dumps of former coal mines such as Baia Nouă deserve SSSI (Site of Special Scientific Interest) status. The Carboniferous list of the Sirinia Basin counts 116 taxa, but this list is under constant revision due to difficulties related to type collections and previous publications.

Pteridophytes include sphenopsids such as Calamites carinatus Sternberg, 1825, Sphenophyllum cuneifolium (Sternberg) Zeiller, lycopsids such as Sigillaria tesselata Brongniart, 1837, Stigmaria ficoides (Sternberg) Brongniart, 1822, and ferns such as Pecopteris arborescens Brongniart, and P. cyathea Brongniart, among many other species. Gymnosperms are represented by pteridosperms such as Neuralethopteris rectinervis (Kidston) Laveine, 1967 and N. schlehanii (Stur) Cremer, 1893 and conifers such as Cordaites principalis (Germar) Geinitz, 1855.

\section{Pteridophyta Lycopsida \\ Lepidodendrales \\ Lepidodendraceae \\ Genus Lepidophloios Sternberg, 1825}

Genus Lepidophloios is rarer and less diverse than genus Lepidodendron Sternberg, and it is defined mainly by its broader than long leaf cushions (Crookal, 1929; Josten, 1991; Cleal and Thomas, 1994; Thomas et al., 2013). Sublepidophloios Sterzel, 1907 is also similar, with an intermediary position between Lepidodendron and Lepidophloios (Thomas et al., 2013). In Romania, the genus Lepidophloios was never cited, described or illustrated (Popa, 2005).

\section{Lepidophloios acerosus Lindley and Hutton, 1831 (Fig. 2a-c)}

1831 Lepidophloios acerosum Lindley and Hutton, (Fig. 1); 1910 Lepidophloios acerosus Renier, Pl. 8; 1929 Lepidophloios acerosus Crookal, p. 25-26, Pl. III, l; pl. XXII, k; 1994 Lepidophloios acerosus Cleal and Thomas, p. 71, text-fig. 24A, B, Pl. 4, figure 3; 2011 Lepidophloios acerosus Psenicka and Oplustil, p. 65, pl. II, figures 1-2; 2014 Lepidophloios acerosus Oplustil et al., p. 784, figure 7; figure 9A, B. 


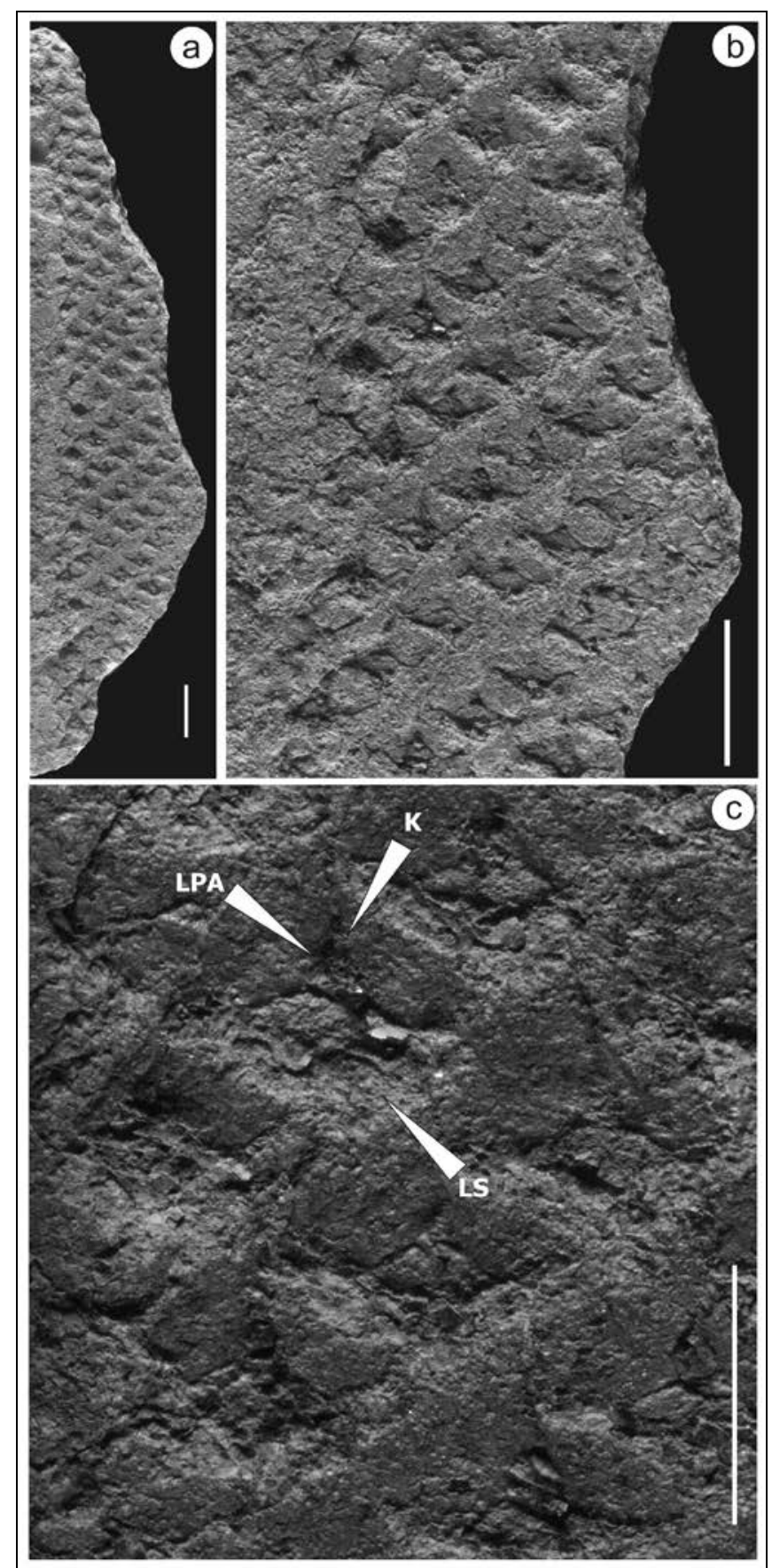

Figures 2a, b, c: Lepidophloios acerosus Lindley and Hutton, Dragosela Valley, Sirinia Basin, South Carpathians, stored in the Laboratory of Palaeontology, University of Bucharest as sample P377/C6/1. a. General view of the plant fragment, scale bar: $10 \mathrm{~mm}$; b. Detail, showing leaf cushions, scale bar: $10 \mathrm{~mm}$; Detail, showing enlarged leaf cushions.

LS: leaf scar, K: keel, LPA: ligule pit aperture, scale bar: $5 \mathrm{~mm}$. 


\section{Description}

An external cast of a trunk shows rhomboidal leaf cushions which are little broader than long, arranged spirally (Figs. 2a, b and c). The lower end or bulge of the leaf cushions is rather rounded, while their upper end is acute. The leaf scar occurs towards the base of the leaf cushion (Fig. 2c) and it is connected to the upper end of the leaf cushion through a prominent keel. The two other lateral keels are difficult to observe. The ligule pit aperture occurs just above the leaf scar (Fig. 2c). The leaf cushions are 6-7 mm wide and 5-6 $\mathrm{mm}$ long, and the leaf scars are 3-4 mm wide and 2-3 mm long (Fig. 2c).

\section{Remarks}

The shape of the leaf cushions, the lower position of the leaf scar and the prominent keel point to Lepidophloios acerosus Lindley and Hutton 1831. A similar species to Lepidophloios acerosus is L. laricinus Sternberg 1825, but the latter has much broader than long leaf cushions, a central position of the leaf scar and a less prominent keel.

Oplustil et al. (2014) consider Lepidophloios acerosus a canopy taxon, recording it within the lower part of the Radnice Member of the Kladno Formation, in Ovcin, Czech Republic. There, Lepidophloios acerosus is recorded as Bolsovian (Westphalian C) in age. The species was reported also from Ovcin and Svinna, by Oplustil et al. (2009), and from the Ujezd u Svateho Krize Coalfield in the Radnice Basin, where it is Bolsovian in age (Psenicka and Oplustil, 2011). In West Yorkshire, Lepidophloios acerosus is Langsettian (basal Westphalian or Westphalian A) in age (Cleal and Thomas, 1994). Cleal (2008) reported this species from the Etruria Formation, South Staffordshire Coalfield, where it may reach Bolsovian age, and also from northern Devon, within the upper Bideford Formation (Cleal and Thomas, 2004). In South Wales, within the Millstone Gritt sequences, Lepidophloios acerosus may reach even Namurian age (Cleal et al., 2009). Another occurence of Lepidophloios acerosus is reported from Dobrogea Coalfield (Tenchov, 1987; Cleal et al., 2009), Westphalian in age.

Lepidophloios acerosus may indicate any age in Sirinia Basin, including Langsettian, which is consistent with the ages marked by the assemblage with Neuralethopteris schlehanii and $N$. rectinervis in Baia Nouă, in the eastern part of the basin (Popa and Cleal, 2012). This could prove a wider development of Langsettian deposits in the Sirinia Basin, also in the western part, in Dragosela Valley. However, as Lepidophloios acerosus was reported elsewhere as Bolsovian in age, its occurrence in Dragosela Valley may be relevant for this age too. A Bolsovian age of Lepidophloios acerosus in the area is consistent with the Bolsovian Cantabrian age of the Cucuiova Formation in Dragosela Valley, as this age was previously considered by Popa (2005). Lepidophloios acerosus may have no stratigraphic significance, as it could be recorded from Langsettian to Asturian (Barry T., pers. comm.).

Nevertheless, Lepidophloios acerosus is a coal generator, occurring in wet habitats such as the edges of coal producing mires. Libertin et al. (2009) reported Lepidophloios acerosus from distal floodplain paleosoils, above coal seams, from the Intra-Sudetic Basin, Czech Republic. Lepidophloios species marked various Late Carboniferous wet intervals, such as L. harcourtii (Witham) Seward and Hill for the Langsettian substage and L. hallii (Evers) DiMichele 1979 for the Westphalian D substage (Cleal, 1991).

\section{Material and occurrence}

Only a single fragment, rather badly preserved, recorded on hand specimen P37/C6/1 (Figs. 2a-c) was collected by Săvescu B. on the sterile dump of a former coal gallery in Dragosela Valley, in the northern-central area of the "Iron Gates" Natural Park. The fragment is curated in the collections of the Laboratory of Palaeontology, University of Bucharest. 


\section{CONCLUSIONS}

The Carboniferous Cucuiova Formation of the Sirinia Basin outcrops scarcely within the Almăj Mountains, therefore its fossil plants are difficult to collect. Although they are usually poorly preserved, these fossils represent significant geological heritage values of the "Iron Gates" Natural Park, occurring especially in Baia Nouă, Cucuiova-Povalina and Dragosela localities, all of them being collected from the sterile dumps of former coal mines or rarely from small sized outcrops. In the Dragosela Valley, a former coal mine's sterile dump permitted to record a rare Lepidophloios acerosus fragment, the first report of this genus and species in Romania.

\section{ACKNOWLEDGMENTS}

The author acknowledges graduate students Mr. Săvescu B. and Ms. Pirnea R. (University of Bucharest) for their enthusiastic help in the field work, Mr. Barry T. (University of Wales at Aberystwyth) is thanked for useful discussions on the systematics of genus Lepidophloios. Mrs. Pătroescu M. (University of Bucharest) and Mrs. Angela-Curtean Bănăduc ("Lucian Blaga” University of Sibiu) are thanked for encouraging this scientific paper. This paper was supported financially through the research grant PN-II Partnership framework no. 31-063/2007 "Paleoclim" to M. E. P. (PI).

\section{REFERENCES}

1. Biţoianu C., 1966 - Asupra prezenței speciei Cellulasclerotes giganteus în depozitele carbonifere de pe Valea Dragosella (Banat), Studii şi cercetări de geologie, geofizică, geografie, Secţia geologie, 11, 2. (in Romanian)

2. Biţoianu C., 1972a - Observaţii asupra conţinutului paleobotanic al depozitelor carbonifere din zona Baia Nouă (Banat), Studii şi cercetări de geologie, geofizică, geografie, Secţia geologie, 17, 125-130. (in Romanian)

3. Biţoianu C., 1972b - Conţinutul floristic al depozitelor carbonifere din zona Sviniţa, Studii şi cercetări de geologie, geofizică, geografie, Secţia geologie, 17, 391-399. (in Romanian)

4. Biţoianu C., 1973 - La flore du Carbonifere superieur de la Roumanie, Septieme Congres International de Stratigraphie et de geologie du Carbonifere, Krefeld, 115-127. (in French)

5. Biţoianu C., 1974 - Le Silezien des Carpathes Meridionales (Roumanie), Bulletin de la Societe Belge de Geologie, Paleontologie et Hydrologie, 83, 131-133. (in French)

6. Biţoianu C., 1987 - Consideraţii paleobotanice, petrografice şi genetice asupra huilelor carbonifere din Banat, Contribuţii Botanice, 89-97. (in Romanian)

7. Biţoianu C. and Ilie S., 1968 - Asupra prezenţei sclerotinitului în huila Carboniferă de pe Valea Dragosella (Banat), Studii şi cercetări de geologie, geofizică, geografie, Secţia geologie, 13, 243-247. (in Romanian)

8. Cleal C. J., 1991 - Carboniferous and Permian biostratigraphy, in Cleal C. J. (ed.), Plant fossils in geological investigation, London, Ellis Horwood, 182-215.

9 Cleal C. J., 2008 - Westphalian-Stephanian macrofloras of the southern Pennines Basin, UK, Studia Geologica Polonica, 129, 25-41.

10. Cleal C. J. and Thomas B. A., 1994 - Plant fossils of the British Coal Measures, The Palaeontological Association, London, 222.

11. Cleal C. J. and Thomas B. A., 2004 - Late Carboniferous palaeobotany of the upper Bideford Formation, north Devon: a coastal setting for a Coal Measures flora, Proceedings of the Geologists Association, 115, 267-281. (in French)

12. Cleal C. J., Oplustil S., Thomas B. A. and Tenchov Y. G., 2009 - Late Moscovian terrestrial biota and palaeoenvironments of Variscan Euramerica, Netherlands Journal of Geosciences, 88, 181-278. 
13. Codarcea A., 1940 - Vues nouvelles sur la tectonique du Banat méridional et du Plateau de Mehedinţi, Dări de semă ale şedinţelor Institutului Geologic Român, 20, 1-74. (in French)

14. Crookall R., 1929 - Coal measure plants, Edward Arnold and Co., London, 80.

15. Dragastan O., Popa M. E. and Ciupercianu M., 1997 - The Late Palaeozoic phytostratigraphy and palaeoecology of the Southern Carpathians (Romania), Primul Simpozion Naţional de Paleontologie, Bucureşti, Acta Palaeontologica Romaniae, 1, 57-64.

16. Hantken M. P., 1878 - Die Kohlenflotze und der Kohlenbergbau in den Landern der ungarischen Krone, Legrady Testeverek, Budapest, 331. (in German)

17. Hauer F., 1870 - Kohlenvorkommen von Berzaska, Fundstelle der Ammoniten von Swinitza, 167. (in German)

18. Ilie S. and Biţoianu C., 1967 - Contribuţii la studiul huilelor de vârstă carboniferă din sinclinalul Dragosela (zona Sviniţa-Svinecea Mare), Dări de seamă ale şedinţelor Comitetului Geologic, 53, 60-68. (in Romanian)

19. Josten K. H., 1991 - Die Steinkohlen-Floren Nordwestdeutschlands, Tafelband, Krefeld, Geologisches Landestamt Nordrhein-Westphalen, 434. (in German)

20. Libertin M., Daskova J., Oplustil S., Bek J. and Edress N., 2009 - A palaeoecological model for a vegetated early Westphalian intramontane valley (Intra-Sudetic Basin, Czech Republic), Review of Palaeobotany and Palynology, 155, 175-203.

21. Maxim I. A., 1967 - Noi contribuţiuni asupra florei fosile de la Sviniţa-Banat, cu o privire comparativă între flora permo-carboniferă din zona Sviniţa, Reşiţa şi sudul Dunării, Studia Universitaria Babeş-Bolyai, Geologia, 2, 9-17. (in Romanian)

22. Maxim I. A., 1969 - Câteva plante din Stephanianul superior de la Sviniţa (Banat), Studii şi cercetări de geologie, geofizică, geografie, Secţia geologie, 14, 405-422. (in Romanian)

23. Năstăseanu S., Stănoiu I. and Biţoianu C., 1973 - Corelarea formaţiunilor molasei hercinice (Westfalian-Permian) din partea vestică a Carpaţilor Meridionali, Anuarul Institutului Geologic, XL, 71-109. (in Romanian)

24. Oplustil S., Psenicka J., Libertin M. and Simunek Z., 2009 - Vegetation patterns of Westphalian and Lower Stephanian mire assemblages preserved in tuff beds of the continental basins of Czech Republic, Review of Palaeobotany and Palynology, 143, 107-154.

25. Oplustil S., Psenicka J., Bek J., Wang J., Feng Z., Libertin M., Simunek Z., Bures J. and Drabkova J., 2014 - T peat forming plant assemblages preserved in growth position by volcanic ash-fall: a case study from the Middle Pennsylvanian of the Czech Republic, Bulletin of Geosciences, 89, 773-818.

26. Petrescu I., Nicorici E., Biţoianu C., Țicleanu N., Todros C., Ionescu M., Mărgărit G., Nicorici M., Duşa A., Pătruţoiu I., Munteanu A. and Buda A., 1987 - Geologia zăcămintelor de cărbuni, 2, Zăcăminte din România, Edit. Tehnică, Bucureşti, 386. (in Romanian)

27. Popa M. E., 2003 - Geological heritage values in the "Iron Gates” Natural Park, Romania, in Pătroescu M. (ed.), ICERA 2003, Ars Docendi Publishing House, Bucureşti, 742-751.

28. Popa M. E., 2005 - Aspects of Romanian Palaeozoic palaeobotany and palynology, II, Overview of the Upper Carboniferous formations in the South Carpathians, Zeitschrift der Deutschen Gesellschaft fur Geowissenschaften, 156, 415-430.

29. Popa M. E., 2011 - Field and laboratory techniques in plant compressions: an integrated approach, Acta Palaeontologica Romaniae, 7, 279-283.

30. Popa M. E. and Cleal C. J., 2012 - Aspects of Romanian Palaeozoic Palaeobotany and Palynology, III, The Late Carboniferous flora of Baia Nouă, Sirinia Basin, Geologia Croatica, 65, 329-243.

31. Preda I., Turculeț I., Bădăluţă A., Barus T. and Androhovici A., 1994 - Geologia zăcămintelor de cărbuni, II, Răspândirea zăcămintelor de cărbuni, Edit. Universităţii din Bucureşti, Bucureşti, 392. (in Romanian)

32. Psenicka J. and Oplustil S., 2011 - Fossil flora from the Ujezd u Svateho Krize Coalfield (Bolsovian, Pennsylvanian), Radnice Basin, Czech Republic, Folia, 45, 61-94. 
33. Răileanu G., 1953 - Cercetări geologice în regiunea Sviniţa-Faţa Mare, Buletin Ştiinţific, 5, 307-409. (in Romanian)

34. Răileanu G., Grigoraş N., Oncescu N. and Plisca T., 1963 - Geologia zăcămintelor de cărbuni, cu privire specială asupra teritoriului R. P. România, Bucureşti, 344. (in Romanian)

35. Schafarzik F., 1894 - Die geologischen Verhaltnisse der umgebung von Eibenthal-UjbanyaTiszovicza und Seinicza im Krasso-Szorenyer Komitate, Jahrbuch de koniglisch ungarische geologische anstaldt A., (1892). (in German)

36. Schafarzik F., 1912 - Geologische Reambulation in der Umgebung von Berszaska, Jahrbuch de koniglisch ungarische geologische anstaldt A., (1910). (in German)

37. Semaka A., 1962 - Observaţii asupra florelor paleomesozoice din Danubianul Banatului, Dări de Seamă ale Şedinţelor Comitetului Geologic, XLVII, 309-321. (in Romanian)

38. Semaka A., 1970 - Geologisch-Paleobotanische Untersuchungen in S. O. Banaten Danubikum, Memorii, XI, 1-79. (in German)

39. Stănoiu I. and Stan N., 1986 - Litostratigrafia molasei permian-carbonifere din regiunea Munteana-Sviniţa-Tîlva Frasinului (Banatul de Sud), Dări de Seamă ale Institutului de Geologie și Geofizică, 70-71, 39-50. (in Romanian)

40. Stur D., 1870 - Beitrage zur kenntnis der Dyas und Steinkohlen-formation im Banate, Jahrbuch der kaiserlich-koniglichen geologische Reichsanstalt, 20, 185-200. (in German)

41. Tenchov Y. G., 1987 - Les flores fossiles de Bulgarie, I.1, Paleozoique, Flore fossile, Megaflore, 1, Sphenopsida et Lycopsida, Sofia, Bulgarian Academy of Sciences, 165. (in French)

42. Thomas B. A., Tenchov Y. G. and Howell A., 2013 - A New Look at the Carboniferous Lepidodendroid Stem Genus Sublepidophloios Sterzel, International Journal of Plant Sciences, 174, 317-327.

43. Tietze E., 1872 - Geologische und Palaeontologischen Mitteilungen aus dem sudlichen Theil der Banater Gebirgstockes, Jahrbuch der kaiserlich-koniglichen geologische, Reichsanstalt, 22. (in German) 